\title{
ANALISIS KEUNGGULAN KOMPETITIF BEBERAPA TANAMAN PANGAN UTAMA DI KABUPATEN CIAMIS
}

\author{
Oleh \\ TITO HARDIYANTO \\ Fakultas Pertanian Universitas Galuh \\ e-mail:thardiyanto17@gmail.com \\ CECEP PARDANI \\ Fakultas Pertanian Universitas Galuh \\ e-mail :alfarhanic@gmail.com
}

\begin{abstract}
Abstrak
Kabupaten Ciamis telah mengembangkan komoditas pangan utama dalam kerangka agribisnis dengan komoditas pangan utamanya adalah padi, jagung, dan kedelai, produktivitas tiga komoditas pangan utama di Kabupaten Ciamis tersebut lebih tinggi dibandingkan produktivitas di Provinsi Jawa Barat maupun Nasional. Namun sayangnya, belum dapat diketahui keunggulan kompetitifnya, karena pada dasarnya komoditas pangan utama yang diusahakan Kabupaten Ciamis sama dengan komoditas di kabupaten lain seperti Kota Banjar, Kabupaten Tasikmalaya, dan Kabupaten Majalengka, ditambah lagi sebagian komoditas pangan dari Provinsi Jawa Tengah juga dipasarkan di Kabupaten Ciamis.

Penelitian ini dilaksanakan dengan tujuan untuk mengetahui : (1) Keunggulan kompetitif dari tanaman pangan utama di Kabupaten Ciamis, (2) Efisiensi usahatani dari tanaman pangan utama di Kabupaten Ciamis.

Metode penelitian dilaksanakan dengan menggunakan metode survai yang berlokasi pada 2 kecamatan yaitu Kecamatan Cijeungjing dan Kecamatan Banjarsari, dengan pertimbangan bahwa dua kecamatan tersebut memiliki produktivitas tertinggi dari salah satu pangan utama (padi, jagung, kedelai) di Kabupaten Ciamis. Penentuan petani responden dilakukan secara acak sederhana (simple random sampling) sebanyak 62 orang petani.

Alat analisis untuk mengetahui tingkat keunggulan kompetitif dari tanaman pangan utama di Kabupaten Ciamis dilakukan melalui pendekatan produktivitas, karena menurut Ramli dan Swastika (2005), Analisis keunggulan kompetitif pada dasarnya analog dengan penentuan tingkat produktivitas minimal dari suatu komoditas agar kompetitif terhadap usahatani komoditas lain. Sedangkan untuk mengetahui tingkat efisiensi usahatani dilakukan dengan cara membandingkan nilai R/C dari tiga komoditas pangan utama.

Berdasarkan hasil penelitian diperoleh kesimpulan sebagai berikut : (1) Kedelai memiliki nilai R/C lebih besar dibanding komoditas padi sawah dan jagung, oleh karena itu usahatani kedelai lebih efisien dibandingkan usahatani padi sawah dan jagung. (2) Produktivitas minimum padi agar kompetitif terhadap kedelai adalah 4.099 ton/ha sedangkan produktivitas minimum jagung agar kompetitif terhadap kedelai adalah 2.722 ton/ha. (3) Harga minimum padi agar kompetitif terhadap kedelai adalah Rp. 3.425 per kilogram sedangkan harga minimum jagung agar kompetitif terhadap kedelai adalah Rp. 3.734 per kilogram.
\end{abstract}


Kata kunci: tanaman pangan utama, keunggulan kompetitif, produktivitas, efisiensi

PENDAHULUAN

Peningkatan ketahanan pangan merupakan prioritas utama dalam pembangunan karena pangan merupakan kebutuhan yang paling dasar bagi manusia sehingga pangan sangat berperan dalam pertumbuhan ekonomi nasional. Ketahanan pangan diartikan sebagai persediaan pangan dalam jumlah dan kualitas yang cukup, terdistribusi dengan harga terjangkau dan aman dikonsumsi bagi setiap warga untuk menopang aktivitasnya sehari-hari sepanjang waktu (Rachman dan Ariani, 2002)

Untuk mewujudkan ketahanan pangan tersebut, maka pengembangan pertanian sekarang ini tidak hanya berorientasi pada satu macam komoditas strategis tetapi juga mencari altenatif komoditas yang dapat menyangga kebijakan swasembada pangan. Menurut Karama (2000), secara nasional, prioritas pertama adalah pengembangan padi, jagung, kedelai, dan ubi kayu. Prioritas kedua adalah pengembangan kacang tanah, kacang hijau, ubi jalar, dan sorgum. Prioritas ketiga adalah serealia, kacangkacangan, dan umbi-umbian lainnya.

Berkaitan dengan hal tersebut, adanya otonomi daerah diperkirakan akan mendorong setiap daerah untuk memproduksi berbagai komoditas pangan dalam kerangka swasembada di tingkat daerah, atau paling tidak mengurangi ketergantungan terhadap daerah lain. Kebijakan ini bisa menjadi tidak menguntungkan bagi perdagangan antar wilayah. Dampak lain dari kebijakan otonomi daerah akan memacu setiap kabupaten untuk menghasilkan komoditas pangan utama yang sesuai dengan kondisi wilayahnya.

Salah satu kabupaten yang telah mengembangkan komoditas pangan utama dalam kerangka agribisnis adalah Kabupaten Ciamis, dengan komoditas pangan utamanya adalah padi, jagung, dan kedelai. Berdasarkan data sekunder dari Dinas Pertanian Tanaman Pangan Kabupaten Ciamis tahun 2014, produktivitas padi di Kabupaten Ciamis mencapai 6,482 ton/ha, jagung mencapai 6,988 ton/ha, sedangkan kedelai mencapai 1,595 ton/ha. Produktivitas tersebut lebih tinggi dibandingkan dengan produktivitas padi, jagung, dan kedelai di Provinsi Jawa Barat. Meskipun produktivitas tiga komoditas pangan utama di Kabupaten Ciamis lebih tinggi dibandingkan produktivitas di Provinsi Jawa Barat, akan tetapi belum dapat diketahui keunggulan kompetitifnya, karena pada dasarnya 
komoditas pangan utama yang diusahakan Kabupaten Ciamis sama dengan komoditas di kabupaten lain seperti Kota Banjar, Kabupaten Tasikmalaya, dan Kabupaten Majalengka, ditambah lagi sebagian komoditas pangan dari Provinsi Jawa Tengah juga dipasarkan di Kabupaten Ciamis.

Pada era perdagangan bebas, semua komoditas pertanian dapat bebas diperdagangkan antar daerah, bahkan antar negara. Konsekuensi dari perdagangan bebas adalah hanya komoditas yang mempunyai keunggulan kompetitif saja yang dapat bersaing.

Merujuk pada keadaan tersebut, maka perlu diketahui komoditas pangan utama yang memiliki keunggulan kompetitif di Kabupaten Ciamis sehingga dalam pengembangannya dapat menguntungkan bagi petani dan mendukung terhadap program swasembada pangan.

\section{TINJAUAN PUSTAKA}

\section{Keunggulan Kompetitif dan Efisiensi Usahatani}

Analisis keuggulan kompetitif pada dasarnya analog dengan penentuan tingkat produktivitas minimal dari suatu komoditas agar kompetitif terhadap usahatani komoditas lain (Ramli dan
Swastika, 2005). Kemudian Adnyana, Kariyasa, dan Sudana (1994) menyatakan, bahwa tingkat persaingan komoditas yang diusahakan dapat didekati dari dua sisi, yaitu sisi tingkat produksi dan sisi tingkat harga. Analisis keunggulan kompetitif produksi dan harga akan memberikan gambaran pada tingkat produksi minimal atau harga minimal berapa suatu komoditas dapat memberikan keuntungan yang bersaing dengan komoditas pesaingnya.

Untuk mengetahui seberapa jauh komoditas yang diusahakan mampu bersaing dengan komoditas pesaingnya, ada beberapa kondisi yang harus diperhatikan (Adnyana dan Kariyasa, 1995) yaitu :

1) Komoditas pembandingnya adalah komoditas yang umumnya ditanam pada hamparan dan musim yang sama.

2) Umur komoditas pembandingnya relatif hampir sama.

3) Produksi dan harga komoditas pembandingnya tidak mengalami perubahan.

4) Biaya produksi komoditas yang dibandingkan maupun pembandingnya hampir sama.

Ramli dan Swastika (2005) menyatakan, analisis lain yang dapat 
digunakan untuk membantu mengetahui keunggulan kompetitif adalah $\mathrm{R} / \mathrm{C}$, titik impas produksi, dan titik impas harga. Sedangkan Rahim dan Hastuti (2007) menyatakan, analisis R/C dapat digunakan untuk mengetahui tingkat efisiensi suatu usaha.

$\mathrm{R} / \mathrm{C}$ adalah analisis imbangan antara penerimaan dengan biaya yang dapat digunakan untuk melihat kelayakan suatu cabang usahatani, bila R/C lebih besar dari satu maka usahatani tersebut berarti menguntungkan, artinya setiap satu rupiah biaya yang dikeluarkan akan memberikan penerimaan lebih dari satu rupiah. Jika R/C lebih kecil dari satu maka usahatani tidak menguntungkan, artinya setiap satu rupiah biaya yang dikeluarkan akan mendatangkan penerimaan kurang dari satu rupiah. Bila R/C sama dengan satu maka usahatani tersebut berarti tidak untung tidak rugi, artinya setiap satu rupiah biaya yang dikeluarkan akan memberikan penerimaan satu rupiah pula. Dalam suatu usaha, perhitungan nilai imbangan ini dapat memperkirakan tingkat keuntungan usaha tersebut (Rahim dan Hastuti, 2007). R/C juga menggambarkan tingkat efisiensi dari suatu usahatani.

\section{Tanaman Padi}

Tanaman padi termasuk keluarga rumput-rumputan (Famili Gramineae). Batangnya beruas-ruas yang di dalamnya berongga, tingginya 1 sampai 1,5 meter. Pada tiap-tiap buku batang tumbuh daun yang berbentuk pita dan berpelepah. Padi termasuk golongan tanaman semusim yaitu tanaman yang berumur pendek, kurang dari satu tahun dan hanya satu kali berproduksi. Tanaman padi dapat dikelompokkan dalam dua bagian yaitu bagian vegetatif yang terdiri dari akar, batang dan daun. Sedangkan bagian generatif terdiri dari malai atau bulir, bunga dan buah dalam bentuk gabah (Soemartono, 2010).

Selanjutnya Soemartono (2010) menyatakan, syarat tumbuh yang harus diperhatikan yaitu iklim, padi dapat tumbuh baik di daerah-daerah yang bersuhu panas dan udara banyak mengandung uap air. Padi menghendaki tempat dan lingkungan yang terbuka, yang banyak mendapatkan sinar matahari. Sebagai media tanam yang dikehendaki mempunyai struktur tanah lapisan atas (top soil) kurang lebih 20 sampai 30 centimeter. Jika telah diolah akan menjadi lumpur yang bentuknya seperti bubur dan banyak mengandung bahan organik. Untuk 
pertumbuhannya, padi sangat membutuhkan air sehingga sawah harus dapat digenangi air, maka dari itu bidang tanah yang ditanami padi terlebih dahulu harus dibuat petak-petak dikelilingi oleh pematang. Dengan adanya pematang tersebut, air dapat ditampung untuk menggenangi tanah sawah. Tanaman padi juga dapat tumbuh di dataran rendah sampai ketinggian 1.300 meter di atas permukaan laut, lebih tinggi lagi padi tidak diusahakan orang, karena tumbuhnya lambat dan hasilnya rendah sehingga penggunaan tanah kurang ekonomis.

\section{Tanaman Jagung}

Jagung merupakan salah satu jenis bahan makanan yang mengandung sumber karbohidrat. Produksi jagung hingga kini dikonsumsi oleh manusia dalam berbagai bentuk penyajian. Buah jagung yang masih muda, terutama jenis jagung manis (sweet corn) sangat disukai orang dan biasanya disajikan dalam bentuk jagung rebus atau jagung bakar. Selain itu juga sering dijumpai tepung jagung atau tepung maizena dan minyak jagung. Kandungan zat makanan yang tinggi dalam jagung menjadikan jagung diolah menjadi berbagai masakan dengan bentuk penyajian yang memikat. Variasi bentuk penyajian bisa meningkatkan permintaan komoditi jagung dari para konsumen.

Menurut Erwidodo, Hermanto dan Pudjihastuti (2003), produk baru seperti minyak goreng dari jagung terus meningkat seiring dengan meningkatnya pendapatan dan kesadaran masyarakat akan bahan makanan yang lebih sehat. Minyak goreng dari jagung mempunyai kandungan kolesterol yang lebih rendah dibandingkan minyak sawi dan minyak kelapa. Yang perlu juga diperhitungkan adalah berkembangnya industri rumah tangga yang menggunakan jagung, yang tidak tercatat dalam Statistik Industri BPS. Perkembangan ini memberikan indikasi bahwa permintaan jagung diperkirakan akan terus meningkat di masa mendatang sebagai akibat dari meningkatnya ragam dan kapasitas industri pengolah.

Usahatani jagung di Indonesia sebagian besar ditanam di lahan kering (79\%) dan sebagian lagi (21\%) di lahan sawah irigasi atau tadah hujan. Cara bercocok tanam yang baik diantaranya adalah waktu tanam yang tepat, pengolahan tanah yang baik, pemupukan yang cukup, pemeliharaan yang teratur, pengairan yang sesuai dengan kebutuhan, pengendalian hama dan penyakit serta 
pemanenan dan pemungutan hasil yang tepat dan baik (Suprapto, 2010).

Jagung dapat hidup baik di daerah beriklim panas dan daerah beriklim sedang, tumbuh baik pada temperatur $23^{\mathrm{O}} \mathrm{C}$ sampai $27^{\mathrm{O}} \mathrm{C}$, suhu minimum yang menghambat pertumbuhan tanaman jagung $3^{\mathrm{O}} \mathrm{C}$ dan suhu maksimum $45^{\circ} \mathrm{C}$. Distribusi curah hujan yang merata selama pertumbuhan juga akan memberikan hasil yang baik, distribusi curah hujan yang ideal bagi pertumbuhan tanaman jagung lebih dari $200 \mathrm{~mm}$ tiap bulan (Suprapto, 2010).

\section{Tanaman Kedelai}

Kedelai berumur pendek hanya satu musim tanam (80-100 hari). Pertumbuhan akan baik pada ketinggian tidak lebih dari $500 \mathrm{~m}$ dpl, masa kritis kedelai terjadi pada pertumbuhan awal vegetatif, pembentukan bunga, dan pengisian polong (Suprapto, 2002).

Di Indonesia, kedelai ditanam pada tanah bekas sawah dan pada lahan tegalan. Pengolahan tanah yang baik sangat diperlukan apabila kedelai ditanam pada lahan tegalan, sedangkan pada tanah sawah persiapannya cukup dengan membabat jerami padi sampai pada permukaan tanah, kemudian langsung dibuat lubang tanam dengan tugal.

Menurut

Suprapto

(2002), pemupukan yang diperlukan tanaman kedelai meliputi nitrogen $45 \mathrm{~kg}$ per hektar, fosfor $90 \mathrm{~kg}$ per hektar, dan kalium $50 \mathrm{~kg}$ per hektar. Untuk menghasilkan 1 gram bahan kering, kedelai memerlukan air sebnyak 650 gram, dan secara umum kedelai dapat diberi pengairan sebanyak 34 kali selama periode pertumbuhannya sesuai dengan masa peka kekurangan air yaitu setelah tanam, 2-3 minggu sebelum berbunga, pada saat berbunga, dan pada saat pengisian polong.

\section{METODE PENELITIAN}

Metode yang digunakan dalam penelitian ini adalah metode survai, dengan mengambil kasus pada petani yang melaksanakan usahatani padi, jagung, dan kedelai di dua kecamatan yaitu Kecamatan Cijeungjing dan Kecamatan Banjarsari Kabupaten Ciamis.

\section{Penentuan Lokasi dan Sasaran Penelitian \\ Penentuan lokasi penelitian dilakukan secara bertahap dengan terlebih dahulu menetapkan sampel daerah penelitian, dasar utama pemilihan daerah}


sampel adalah kecamatan yang memiliki produktivitas tertinggi dari salah satu diantara komoditas pangan utama yaitu antara padi, jagung, dan kedelai.

Data sekunder dari Dinas Pertanian Tanaman Pangan Kabupaten Ciamis (2014) menunjukkan bahwa Kecamatan Cijeungjing memiliki produktivitas jagung tertinggi dan Kecamatan Banjarsari memiliki produktivitas padi dan kedelai tertinggi diantara kecamatan-kecamatan yang ada di Kabupaten Ciamis. Dengan demikian, dipilih secara sengaja (purposif) Desa Handapherang Kecamatan Cijeungjing dan Desa Kalijaya Kecamatan Banjarsari sebagai lokasi penelitian.

Sasaran penelitian adalah petani yang melaksanakan usahatani padi, jagung, dan kedelai secara kontinu dan intensif, dalam hal ini jumlah petani sampel ditentukan berdasarkan persentase dari keseluruhan jumlah petani di dua lokasi penelitian yaitu sebesar 10 persen. Jumlah anggota populasi di Desa Handapherang Kecamatan Cijeungjing sebanyak 313 orang dan Desa Kalijaya Kecamatan Banjarsari sebanyak 309 orang sehingga diperoleh sampel sebagai sasaran penelitian sebanyak 62 orang petani yang terdiri dari 31 orang petani di Kecamatan
Cijeungjing dan 31 orang petani di Kecamatan Banjarsari.

\section{Peubah yang Diamati/Diukur}

Peubah atau variabel yang diamati/diukur dalam penelitian ini meliputi :

1) Satu kali proses produksi, yaitu dimulai dari pengolahan tanah sampai dengan pemanenan yang berlangsung selama empat bulan.

2) Produktivitas adalah kemampuan lahan untuk menghasilkan produksi.

3) Harga produk adalah harga jual komoditas yang berlaku saat penelitian.

4) Biaya produksi adalah korbanan yang dicurahkan dalam proses produksi sehingga menghasilkan produk yang terdiri dari biaya tetap dan biaya variabel.

5) Penerimaan adalah produksi total dikalikan dengan harga jual yang dinilai dalam satuan rupiah per satu kali proses produksi.

6) Pendapatan dinilai dalam satuan rupiah per satu kali proses produksi, pendapatan merupakan selisih antara penerimaan dengan biaya produksi total yang dikeluarkan. 
7) Revenue cost ratio (R/C) adalah perbandingan antara penerimaan dan biaya.

\section{Rancangan Analisis Data}

Untuk mengetahui tingkat keunggulan kompetitif dari tanaman

\section{Teknik Pengumpulan Data}

Adapun data yang dikumpulkan meliputi data primer dan data sekunder. Data primer yaitu data yang diperoleh dari hasil wawancara langsung dengan petani menggunakan daftar pertanyaan, sedangkan data sekunder yaitu data yang diperoleh dari lembaga-lembaga yang ada kaitannya dengan permasalahan yang pangan utama di Kabupaten Ciamis dianalisis melalui pendekatan produktivitas. Menurut Ramli dan Swastika (2005), Analisis keunggulan kompetitif pada dasarnya analog dengan penentuan tingkat produktivitas minimal dari suatu komoditas agar kompetitif terhadap usahatani komoditas lain, kerangka analisis disajikan pada Tabel 1. sedang diteliti, serta hasil-hasil penelitian terdahulu yang ada kaitannya dengan penelitian ini.

Tabel 1. Kerangka Analisis Keunggulan Kompetitif Suatu Komoditas

\begin{tabular}{|l|l|l|l|l|l|}
\hline No & Komoditas & $\begin{array}{l}\text { Produktivitas } \\
\text { (ton/ha) }\end{array}$ & $\begin{array}{l}\text { Harga } \\
\text { (Rp/Kg) }\end{array}$ & $\begin{array}{l}\text { Biaya } \\
\text { (Rp/Ha) }\end{array}$ & $\begin{array}{l}\text { Keuntungan } \\
\text { (Rp/Ha) }\end{array}$ \\
\hline 1 & Komoditas A & Y1 & H1 & D1 & E1 \\
\hline 2 & Komoditas B & Y2 & H2 & D2 & E2 \\
\hline 3 & Komoditas C & Y3 & H3 & D3 & E3 \\
\hline 4 & $\begin{array}{l}\text { Keunggulan komoditas A } \\
- \text { terhadap B } \\
- \text { terhadap C }\end{array}$ & F1 & & & \\
\hline
\end{tabular}

Keterangan : $\mathrm{F} 1=(\mathrm{E} 2+\mathrm{D} 1) / \mathrm{H} 1 \quad \mathrm{P} 1=(\mathrm{E} 2+\mathrm{D} 1) / \mathrm{Y} 1$

$$
\mathrm{F} 2=(\mathrm{E} 3+\mathrm{D} 1) / \mathrm{H} 1 \quad \mathrm{P} 2=(\mathrm{E} 3+\mathrm{D} 1) / \mathrm{Y} 1
$$

Dimana :

F1 = Produktivitas minimum komoditas A agar kompetitif terhadap komoditas B

F2 = Produktivitas minimum komoditas A agar kompetitif terhadap komoditas C

P1 = Harga minimum komoditas A agar kompetitif terhadap komoditas B

P2 = Harga minimum komoditas A agar kompetitif terhadap komoditas C 
Untuk mengetahui tingkat efisiensi usahatani dilakukan dengan cara membandingkan nilai $\mathrm{R} / \mathrm{C}$ dari komoditas yang menjadi tanaman pangan utama di Kabupaten Ciamis. Untuk mengetahui R/C yaitu membandingkan antara penerimaan dengan total biaya produksi (Rahim dan Hastuti, 2007) secara matematis dapat ditulis sebagai berikut :

$$
\mathrm{R} / \mathrm{C}=\frac{\text { Penerimaan Total }}{\text { Biaya Total }}
$$

Dengan ketentuan-ketentuan sebagai berikut :

a) $\mathrm{R} / \mathrm{C}$ lebih besar dari 1 maka usahatani tersebut menguntungkan.

b) R/C sama dengan 1 maka usahatani tersebut tidak untung tidak rugi (impas).

c) R/C kurang dari 1 maka usahatani tersebut rugi.

\section{Dimana :}

$$
\begin{aligned}
& \mathrm{R}=\mathrm{Y} . \mathrm{Hy} \\
& \mathrm{C}=\mathrm{TFC}+\mathrm{TVC}
\end{aligned}
$$

$\mathrm{R}=$ Revenue (Penerimaan Total)

$\mathrm{C}=\operatorname{Cost}($ Biaya Total)

$\mathrm{Y}=$ Quantity (Volume Penjualan)

Hy $=$ Price $($ Harga Jual/Kg)

TFC = Total Fixed Cost (Biaya Tetap Total)
TVC = Total Variable Cost $($ Biaya Variabel Total)

\section{HASIL DAN PEMBAHASAN}

\section{Keadaan Umum Lokasi Penelitian Desa}

\section{Handapherang}

Desa Handapherang merupakan salah satu desa yang berada di wilayah Kecamatan Cijeungjing Kabupaten Ciamis. Secara Geografis Desa Handapherang terletak di sebelah Utara Kecamatan Cijeungjing, terletak pada jarak 4,50 kilometer dari Ibu kota Kecamatan dan 3 kilometer dari Ibu kota Kabupaten dengan luas wilayah keseluruhan 550,525 hektar.

Wilayah Desa Handapherang memiliki ketinggian berkisar antara 134,00 meter di atas permukaan laut (dpl). Adapun temperatur normal atau suhu ratarata 20 derajat celsius sampai dengan 27 derajat celsius. Berdasarkan data curah hujan memiliki rata-rata bulan basah 6,8 dan rata-rata bulan kering 3 sehingga termasuk Tipe C (sedang).

Sebagian besar lahan di Desa Handapherang digunakan untuk lahan pertanian dan ladang. Untuk lahan pertanian meliputi sawah yang mempunyai luas 118,10 hektar, ladang dengan luas 333,83 hektar, kolam dengan luas 113,40 hektar, dan tanah fasilitas umum dengan 
luas 60,255 hektar. Jumlah penduduk Desa Handapherang sebanyak 6.341 orang yang terdiri dari laki-laki 3.116 orang dan perempuan 3.225 orang,

\section{Keadaan Umum Lokasi Penelitian Desa Kalijaya}

Secara geografis Desa Kalijaya memiliki topografi berbukit yang terletak pada ketinggian 450 - 500 meter di atas permukaan laut dengan kemiringan tanah antara $0-15$ persen, jenis tanah alluvial dan podsolik merah kuning. Wilayah Desa Kalijaya dilihat dari topografinya merupakan daerah perbukitan (bergelombang), dengan ketinggian tempat sekitar 450 sampai 500 meter di atas permukaan laut (dpl). Berdasarkan data curah hujan 10 tahun terakhir Desa Kalijaya diperoleh rata-rata curah hujan 2.463 milimeter dan termasuk tipe curah hujan C (agak basah).

Sebagian besar penggunaan lahan di Desa Kalijaya didominasi oleh lahan kering, berupa hutan negara seluas 451 hektar, lahan tegalan atau kebun seluas 151 hektar, pemukiman dan pekarangan seluas 11 hektar, sawah pengairan sederhana 6 hektar, sawah tadah hujan seluas 27 hektar dan areal penggunaan lain seluas 2 hektar. Jumlah penduduk Desa Kalijaya sebanyak
3.081 orang, yang terdiri dari 1.691 orang laki-laki $(54,88 \%)$ dan 1.390 orang perempuan $(45,12 \%)$, dengan jumlah kepala keluarga sebanyak 1.359 KK.

\section{Tingkat efisiensi usahatani di Desa} Handapherang Kecamatan Cijeungjing

Tingkat efisiensi usahatani dari sebuah komoditas dapat terlihat dengan membandingkan $\mathrm{R} / \mathrm{C}$ yang diperoleh dari suatu usahatani. Adapun biaya, penerimaan, pendapatan dan $\mathrm{R} / \mathrm{C}$ masingmasing komoditas adalah sebagai berikut :

- Biaya total usahatani padi sawah adalah sebesar Rp. 11.976.521, biaya total usahatani kedelai adalah sebesar Rp. 3.577.354 dan biaya total usahatani jagung adalah sebesar Rp. 8.636.575 dengan demikian terlihat bahwa biaya usahatani yang terbesar dari tiga komoditas tersebut adalah usahatani padi sawah.

- Rata-rata produksi padi sawah per hektar dalam satu kali proses produksi adalah sebanyak 5.745 kilogram dengan harga jual Rp. 4.800 per kilogram, sehingga rata-rata penerimaan responden sebesar $\mathrm{Rp}$. 28.600.877. Rata-rata produksi kedelai per hektar dalam satu kali proses produksi adalah sebanyak 1.025 
Jurnal Pemikiran Masyarakat Ilmiah Berwawasan Agribisnis. 2017. 3(1): 73-88

kilogram dengan harga jual Rp. 11.000 per kilogram, sehingga ratarata penerimaan responden sebesar Rp. 11.275.000. Rata-rata produksi jagung per hektar dalam satu kali proses produksi adalah sebanyak 4.375 kilogram dengan harga jual Rp. 6.000 per kilogram, sehingga rata-rata penerimaan responden sebesar Rp. 26.249.613.

- Rata-rata R/C dari usahatani padi sawah per hektar dalam satu kali proses produksi adalah 2,40, rata-rata $\mathrm{R} / \mathrm{C}$ dari usahatani kedelai per hektar dalam satu kali proses produksi adalah 3,27, dan rata-rata $\mathrm{R} / \mathrm{C}$ dari usahatani jagung per hektar dalam satu kali proses produksi adalah 3,09. Usahatani kedelai memiliki nilai $\mathrm{R} / \mathrm{C}$ lebih besar dibanding komoditas padi sawah dan jagung, oleh karena itu usahatani kedelai lebih efisien dibandingkan usahatani padi sawah dan jagung, dengan demikian komoditas kedelai memiliki keunggulan kompetitif dibanding komoditas padi sawah dan jagung.
Tingkat Keunggulan Kompetitif Dari Tanaman Pangan Utama Di Desa Handapherang

Hasil kajian dari keunggulan kompetitif komoditas padi sawah, kedelai dan jagung di Desa Handapherang Kecamatan Cijeungjing Kabupaten Ciamis dapat dilihat pada Tabel 2 . 
Tabel 2. Analisis Keunggulan Kompetitif Dari Tanaman Pangan Utama di Desa Handapherang Tahun 2016

\begin{tabular}{|l|l|l|l|l|l|}
\hline No & Komoditas & $\begin{array}{l}\text { Produktivitas } \\
\text { (ton/ha) }\end{array}$ & $\begin{array}{l}\text { Harga } \\
(\mathbf{R p / K g})\end{array}$ & $\begin{array}{l}\text { Biaya } \\
(\mathbf{R p / H a})\end{array}$ & $\begin{array}{l}\text { Keuntungan } \\
(\mathbf{R p / H a})\end{array}$ \\
\hline 1 & Komoditas Padi & 5.745 & 4.800 & 11.976 .521 & 16.624 .356 \\
\hline 2 & Komoditas Kedelai & 1.025 & 11.000 & 3.577 .354 & 7.697 .647 \\
\hline 3 & Komoditas Jagung & 4.375 & 6.000 & 8.636 .575 & 17.613 .038 \\
\hline 4 & $\begin{array}{l}\text { Keunggulan komoditas } \\
\text { Padi : }\end{array}$ & & & & \\
& $\begin{array}{l}\text { - terhadap Kedelai } \\
\text { - terhadap Jagung }\end{array}$ & 4.099 & 3.425 & & \\
\hline 5 & $\begin{array}{l}\text { Keunggulan komoditas } \\
\text { Kedelai : }\end{array}$ & & 5.150 & & \\
& $\begin{array}{l}\text { - terhadap Jagung } \\
\text { - terhadap Padi }\end{array}$ & 1.926 & & & \\
\hline 6 & $\begin{array}{l}\text { Keunggulan komoditas } \\
\text { Jagung : }\end{array}$ & 1.837 & 20.674 & & \\
\hline & $\begin{array}{l}19.709 \\
\text { - terhadap Padi } \\
\text { - terhadap Kedelai }\end{array}$ & 4.210 & & & \\
\hline
\end{tabular}

Tabel 2 menunjukkan bahwa produktivitas minimum komoditas padi agar kompetitif terhadap komoditas Kedelai adalah 4.099 ton/ha sedangkan terhadap komoditas jagung adalah 6.164 ton/ha. Produktivitas minimum komoditas kedelai agar kompetitif terhadap komoditas jagung adalah 1.926 ton/ha sedangkan terhadap komoditas padi adalah 6.164 ton/ha. Produktivitas minimum komoditas jagung agar kompetitif terhadap komoditas padi adalah 4.210 ton/ha sedangkan terhadap komoditas kedelai adalah 2.722 ton/ha.

Selanjutnya Tabel 2 menunjukkan bahwa harga minimum komoditas padi agar kompetitif terhadap komoditas kedelai Rp. 3.425 per kilogram, sedangkan terhadap jagung Rp. 5.150 per kilogram. Harga minimum komoditas kedelai agar kompetitif terhadap komoditas jagung Rp. 20.674 per kilogram, sedangkan terhadap padi Rp. 19.709 per kilogram. Harga minimum komoditas jagung agar kompetitif terhadap komoditas padi $\mathrm{Rp}$. 5.774 per kilogram, sedangkan terhadap kedelai Rp. 3.734 per kilogram.

\section{Tingkat Efisiensi Usahatani di Desa} Kalijaya Kecamatan Banjarsari

- Biaya total usahatani padi sawah adalah sebesar Rp. 19.373.459, biaya 
total usahatani kedelai adalah sebesar Rp. 8.751.446 dan biaya total usahatani jagung adalah sebesar Rp. 5.371.039 dengan demikian terlihat bahwa biaya usahatani yang terbesar dari tiga komoditas tersebut adalah usahatani padi sawah.

- Rata-rata produksi padi sawah per hektar dalam satu kali proses produksi adalah sebanyak 9.693 kilogram dengan harga jual Rp. 4.800 per kilogram, sehingga rata-rata penerimaan responden sebesar Rp. 46.524.480. Rata-rata produksi kedelai per hektar dalam satu kali proses produksi adalah sebanyak 6.909 kilogram dengan harga jual Rp. 11.000 per kilogram, sehingga ratarata penerimaan responden sebesar Rp. 41.453.713. Rata-rata produksi jagung per hektar dalam satu kali proses produksi adalah sebanyak 1.562 kilogram dengan harga jual Rp. 6.000 per kilogram, sehingga rata-rata penerimaan responden sebesar Rp. 17.179.132.

- Rata-rata R/C dari usahatani padi sawah per hektar dalam satu kali proses produksi adalah 2,40 . Rata-rata $\mathrm{R} / \mathrm{C}$ dari usahatani kedelai per hektar dalam satu kali proses produksi adalah
4,80, dan rata-rata $\mathrm{R} / \mathrm{C}$ dari usahatani jagung per hektar dalam satu kali proses produksi adalah 3,27. Usahatani kedelai memiliki nilai $\mathrm{R} / \mathrm{C}$ lebih besar dibanding komoditas padi sawah dan jagung, oleh karena itu usahatani kedelai lebih efisien dibandingkan usahatani padi sawah dan jagung, dengan demikian komoditas kedelai memiliki keunggulan kompetitif dibanding komoditas padi sawah dan jagung.

\section{Tingkat Keunggulan Kompetitif Dari Tanaman Pangan Utama Di Desa Kalijaya \\ Hasil kajian dari keunggulan} kompetitif komoditas padi sawah, kedelai dan jagung di Desa Kalijaya Kecamatan Banjarsari Kabupaten Ciamis dapat dilihat pada Tabel 3. 
Tabel 3. Analisis Keunggulan Kompetitif Dari Tanaman Pangan Utama di Desa Kalijaya Tahun 2016

\begin{tabular}{|c|c|c|c|c|c|}
\hline No & Komoditas & $\begin{array}{l}\text { Produktivitas } \\
\text { (ton/ha) }\end{array}$ & $\begin{array}{l}\text { Harga } \\
(\mathrm{Rp} / \mathrm{Kg})\end{array}$ & $\begin{array}{l}\text { Biaya } \\
\text { (Rp/Ha) }\end{array}$ & $\begin{array}{l}\text { Keuntungan } \\
\text { (Rp/Ha) }\end{array}$ \\
\hline 1 & Komoditas Padi & 9.693 & 4.800 & 19.373 .459 & 27.151 .020 \\
\hline 2 & Komoditas Kedelai & 6.909 & 11.000 & 8.751 .446 & 32.702 .267 \\
\hline 3 & Komoditas Jagung & 1.562 & 6.000 & 5.371 .039 & 11.808 .093 \\
\hline 4 & $\begin{array}{l}\text { Keunggulan komoditas } \\
\text { Padi : } \\
\text { - terhadap Kedelai } \\
\text { - terhadap Jagung }\end{array}$ & $\begin{array}{l}10.849 \\
6.496\end{array}$ & $\begin{array}{l}5.373 \\
3.217\end{array}$ & & \\
\hline 5 & $\begin{array}{l}\text { Keunggulan komoditas } \\
\text { Kedelai : } \\
\text { - terhadap Jagung } \\
\text { - terhadap Padi }\end{array}$ & $\begin{array}{l}1.869 \\
3.264\end{array}$ & $\begin{array}{l}2.976 \\
5.196\end{array}$ & & \\
\hline 6 & $\begin{array}{l}\text { Keunggulan komoditas } \\
\text { Jagung : } \\
\text { - terhadap Padi } \\
\text { - terhadap Kedelai }\end{array}$ & $\begin{array}{l}5.420 \\
6.346\end{array}$ & $\begin{array}{l}20.821 \\
24.375\end{array}$ & & \\
\hline
\end{tabular}

Tabel 3 menunjukkan bahwa produktivitas minimum komoditas padi agar kompetitif terhadap komoditas Kedelai adalah 10.849 ton/ha sedangkan terhadap komoditas jagung adalah 6.496 ton/ha. Produktivitas minimum komoditas kedelai agar kompetitif terhadap komoditas jagung adalah 1.869 ton/ha sedangkan terhadap komoditas padi adalah 3.264 ton/ha. Produktivitas minimum komoditas jagung agar kompetitif terhadap komoditas padi adalah 5.420 ton/ha sedangkan terhadap komoditas kedelai adalah 6.346 ton/ha.

Selanjutnya Tabel 3 menunjukkan bahwa harga minimum komoditas padi agar kompetitif terhadap komoditas kedelai Rp. 5.373 per kilogram, sedangkan terhadap jagung Rp. 3.217 per kilogram. Harga minimum komoditas kedelai agar kompetitif terhadap komoditas jagung Rp. 2.976 per kilogram, sedangkan terhadap padi Rp. 5.196 per kilogram. Harga minimum komoditas jagung agar kompetitif terhadap komoditas padi $\mathrm{Rp}$. 20.821 per kilogram, sedangkan terhadap kedelai Rp. 24.375 per kilogram.

\section{PENUTUP}

Berdasarkan hasil dan pembahasan maka diperoleh kesimpulan sebagai berikut 
1) Kedelai memiliki nilai $\mathrm{R} / \mathrm{C}$ lebih besar dibanding komoditas padi sawah dan jagung, oleh karena itu usahatani kedelai lebih efisien dibandingkan usahatani padi sawah dan jagung, dengan demikian komoditas kedelai memiliki keunggulan kompetitif dibanding komoditas padi sawah dan jagung.

2) Produktivitas minimum padi agar kompetitif terhadap kedelai adalah 4.099 ton/ha sedangkan terhadap jagung adalah 6.164 ton/ha. Produktivitas minimum kedelai agar kompetitif terhadap jagung adalah 1.926 ton/ha sedangkan terhadap padi adalah 6.164 ton/ha. Produktivitas minimum jagung agar kompetitif terhadap padi adalah 4.210 ton/ha sedangkan terhadap kedelai adalah 2.722 ton/ha.

3) Harga minimum padi agar kompetitif terhadap kedelai adalah Rp. 3.425 per kilogram, sedangkan terhadap jagung Rp. 5.150 per kilogram. Harga minimum kedelai agar kompetitif terhadap jagung Rp. 20.674 per kilogram, sedangkan terhadap padi Rp. 19.709 per kilogram. Harga minimum jagung agar kompetitif terhadap padi Rp. 5.774 per kilogram, sedangkan terhadap kedelai Rp. 3.734 per kilogram.

\section{DAFTAR PUSTAKA}

Adnyana, M.O., dan Kariyasa, K. 1995. Model Keuntungan Kompetitif Sebagai Alat Analisis dalam Memilih Komoditas Pertanian Unggulan. Informatika Pertanian. Vol 5 No 2. Badan Litbang Pertanian. Jakarta.

Adnyana, M.O., Kariyasa, K., dan Sudana, W. 1994. Analisis Finansial dan Keunggulan Kompetitif Usahatani Jagung di Jawa Tengah dalam Risalah Seminar Hasil Penelitian Sistem Usahatani dan Sosial Ekonomi. Pusat Penelitian dan Pengembangan Tanaman Pangan. Badan Litbang Pertanian. Jakarta.

Anjayani dan Haryanto. 2009. Geografi. Penerbit Cempaka Putih. Jakarta

Arikunto, S. 2010. Prosedur Penelitian Suatu Pendekatan Praktik. Edisi Revisi 2010. Rineka Cipta. Jakarta.

BPS Provinsi Jawa Barat, 2015. Berita Resmi Statistik BPS Provinsi Jawa Barat No. 19/03/32.Th.XVII. 2 Maret 2015. Bandung.

Daniel, M. 2003. Metode Penelitian Sosial Ekonomi. Bumi Aksara. Jakarta.

Departemen Pertanian. 2006. Budidaya Jagung. Departemen Pertanian RI. Jakarta.

Dinas Pertanian Tanaman Pangan Kabupaten Ciamis. 2015. Laporan Tahunan. Ciamis.

Dinas Pertanian Tanaman Pangan Propinsi Jawa Barat. 2005. Petunjuk 
Teknis

Kegiatan

Pengembangan Produksi

Unggulan Utama Tanaman

Pangan di 16 Kabupaten se-

Jawa Barat APBD Tahun

Anggaran 2005. Bandung.

Hernanto, F. 1988. Ilmu Usahatani. Penebar Swadaya. Jakarta.

Karama, S. 2000. Pemantapan Ketahanan Pangan Nasional dengan Penerapan Pertanian Modern. Seminar Budidaya Pertanian Olah Tanah Konservasi VII. Banjarmasin.

Rachman, P.S. dan Ariani, M. 2002. Ketahanan Pangan : Konsep, Pengukuran, dan Strategi. Jurnal FAE Vol. 20 No. 1.

Rahim, A. dan Hastuti, D. 2007. Pengantar Teori dan Kasus Ekonomika Pertanian. Penebar Swadaya. Jakarta.

Ramli, R. dan Swastika, D.K.S. 2005. Analisis Keunggulan Kompetitif Beberapa Tanaman Palawija Di Lahan Pasang Surut Kalimantan Tengah. Jurnal Pengkajian dan Pengembangan Teknologi Pertanian Vol.8 No.1. Pusat Penelitian dan Pengembangan Sosial Ekonomi Pertanian. Bogor.

Soekartawi. 2002. Ilmu Usahatani dan Penelitian Untuk Perkembangan Petani Kecil. Universitas Indonesia. Jakarta. . 2005. Prinsip Dasar Ekonomi Pertanian Teori dan Aplikasinya. Rajawali Press. Jakarta.

Soemartono. 2010. Bercocok Tanam Padi. Yasaguna. Jakarta.

Sugeng, H.R. 2009. Bercocok Tanam Padi. Aneka Ilmu. Semarang.

Suhardiyono, L. 1989. Perkembangan Struktur Produksi,
Ketenagakerjaan dan Pendapatan Rumah Tangga Pedesaan. Pusat Penelitian Agro Ekonomi Badan Penelitian dan Pengembangan Pertanian. Bogor

Suprapto, H.S. 2002. Bertanam Kedelai. Penebar Swadaya. Jakarta.

Suprapto, H.S. 2010. Bertanam Jagung. Penebar Swadaya. Jakarta.

Suratiyah, K. 2009. Ilmu Usaha Tani. Penebar Swadaya. Jakarta.

Wirosuharjo. 2004. Dasar-Dasar Demografi. Fakultas Ekonomi Universitas Indonesia. Jakarta. 